\title{
Methodology for assessing the economic efficiency of investment projects in petrochemical companies
}

\author{
Tatiana Bondarenko* and Aleksei Bolvachev \\ Plekhanov Russian University of Economics, Russia, 117997, Moscow, Stremyanny per. 36
}

\begin{abstract}
The article focuses on the issues of investment potential of petrochemical companies and the need to develop a unified approach transparent for all the participants, to assess the efficiency of investment projects in petrochemical companies. The proposed methodology is to be applied to scheduling project costs and in fact, to ground the establishment of annual financing limits for a project. Additionally, the methodology is expected to reflect the possibility of updating the main indicators, both for financing the purchase of domestic and imported equipment. The methodology also takes into account the mechanism of contract pricing, recalculation of the cost of works and services is performed according to the rules and regulations approved for the estimates in any petrochemical company, inclusive of the indices of changes in current estimated cost to base period prices. The proposed methodology for assessing the performance indicators of investment projects is one of the most multi-faceted and optimal tools for petrochemical companies for attracting additional funding from both their own and other sources. In the conditions of growing business volumes, and in case of complying with the recommendations of the state strategy for the industry growth until 2030, the proposed methodology is transparent and relevant to all the investment participants in terms of cash flow generation for the project.
\end{abstract}

\section{Introduction}

\section{Relevance of the Research Topic}

Russia is one of the leading oil and gas producers, however, its share of petrochemical production accounts for only $2 \%$ of the world total. Russian petrochemical production falls behind global leaders - China, the United States and Saudi Arabia by 5-8 times [1].

The development of the petrochemical industry is fully represented in the document "The Strategy for the development of the chemical and petrochemical complex until 2030", which determines the future priorities and target indicators of the petrochemical industry [2].

Despite the significant reduction in Russia's investment attractiveness both during the global crisis of 2008-2009 and poorly performing economy of 20142016, the general trends and structure of investment did not undergo substantial changes. In general, after the stabilization of the economic situation in 2013, the share of investments in machinery, equipment and vehicles in the structure of fixed investments reached a level of $38.8 \%$. Thereafter, there was a serious decline, and in 2015-2017, the indicator achieved a 15 - year minimum and constituted $31.5 \%$ [3].

In recent years, the petrochemical industry in Russia has achieved some success, due to increased investment and starting up several large-scale production facilities. In 2010-2017, the production of large-capacity polymers in Russia grew by $58 \%$ and reached 5,4 million tons [4]. The growth was ensured by investment increase in the industry and the commissioning of new large-scale industries.

The priorities in the development of the petrochemical industry in the Russian Federation until 2030, declared at the international conference "Gas and Petrochemical Industry - 2030" are worth noting: prioritization of problems according to the degree of influence of the main segments of petrochemical companies on competitiveness is presented in Figure 1.

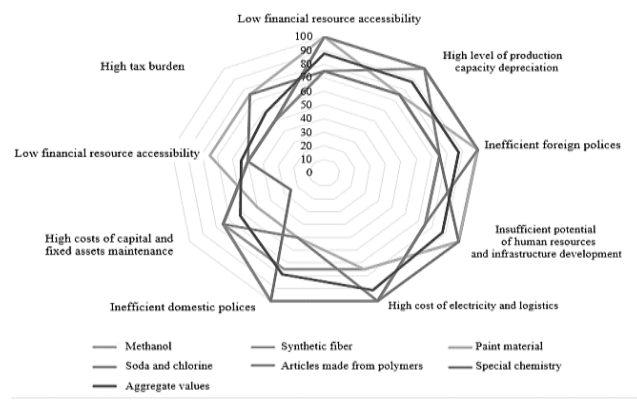

Fig. 1. The degree of combined impact of individual segments of Russian petrochemical industry on the final index of competitiveness.

The Strategy for the development of the chemical and petrochemical complex of Russia until 2030, approved in 2016, presupposes the increased consumption of all the types of primary raw materials; naphtha and liquefied petroleum gases by $2-2,5$ times, ethane - by 5 times. The

\footnotetext{
* Corresponding author: t.g.bondarenko@ @mail.com
} 
growth in ethane use will primarily take place due to processing wet gas from new fields in Eastern Siberia and the Far East (Kovykta and Chayanda). By 2030, the production of large-capacity polymers will be increased up to 14,4 million tons (almost by 3 times, as compared with 2017), while their consumption will double. Thus, by 2025 , due to growing production, Russia is likely to become a major exporter of large-capacity polymers (net exports will account for 6,4 million tons), primarily, polyethylene and polypropylene. The main volume of new production will be distributed between two plants ZapSibNeftekhim and Amursky Chemical Plant, which together will ensure the production of 3 million tons of polyethylene per year. The products are going to be exported mainly to foreign markets: the European and of the countries of the Asia-Pacific region. [5]

Therefore, from this point of view, petrochemistry should be considered one of the top priority directions of Russian economy development. Among the favourable conditions for the development of petrochemistry investment potential are the following:

- A strong raw material base: the availability of relatively cheap and excessive raw materials;

- The presence of groundwork: chemical sector megaprojects - ZapSibneftekhim, Amur Gas Processing Plant, Amur Gas Chemical Plant, Eastern Petrochemical Company, SOCAR GPC, Atyrau Gas Chemical Plant and many other projects, different in scale;

- Considerable potential for increasing the demand for petrochemical products;

- Great potential for exporting petrochemical products to the EU, Chinese and Asian markets.

There has been a large number of theoretical, methodological and applied research on setting development strategies for petrochemical complexes. This is due to changing trends [6], tools [7], [8], development tendencies [9], [10], and approaches to the financing of petrochemical projects in Russia and worldwide [11].

Statistical data, analytical reviews and methodological materials of various analytical agencies were the information and statistical base of the study, as well as regulatory documents of the Russian Federation and economic-oriented articles in Internet publications, materials of international and all-Russian scientific and practical conferences.

Working method and methodology: in the course of the study, the following methods were used: analysis and synthesis, system and comparative analysis, classification and grouping, and a number of other scientific methods.

In order to increase the investment potential of petrochemical companies, it is essential to develop a unified methodology for evaluating investment projects in the industry.

\section{Main principles of estimating investment projects efficiency in petrochemical companies}

The effectiveness of investment projects implies that project results are consistent with the goals and interests of their participants [12]. A project is considered economically efficient if it can ensure the return of invested capital within a reasonable time and generate certain income.

Evaluation of investment project effectiveness should be based on common basic principles applicable to any type of project, regardless of its technical, technological, financial, industrial or regional characteristics:

- project review throughout its life cycle (estimated period) - from conducting pre-investment research up to project finish;

- modelling cash flows, including all cash receipts and expenditures related to project implementation for the billing period, taking into account the possible use of different currencies;

- consistent conditions for comparing different projects (project variants);

- the principle of positivity and maximum effect. In order for the investment project to be recognized effective from the investor's point of view, it is essential that the effect of its implementation is positive; when comparing alternative investment projects, the preference should be given to the project with the greatest effect value;

- time management. When evaluating the project effectiveness, various aspects of the time factor should be taken into consideration, including the dynamism (changing with time) of the project parameters and economic environment; temporal dislocation between the production or resources delivery and payment; time transgressive costs and / or results (preference for earlier results and later expenditures);

- accounting only the upcoming costs and revenues. When calculating performance indicators, only the costs and revenues coming up during project implementation should be accounted for, as well as the upcoming losses directly caused by project implementation (for example, suspension of the existing production due to organization of new production in its place). The previously acquired resources being used in the project are estimated by the opportunity cost, reflecting the maximum value of the lost profit in their best possible alternative use. Prior costs are not accounted for in cash flows and do not affect the value of performance indicators;

- "with the project" and "without the project" comparison. Evaluating investment projects efficiency should be carried out not by comparing the "before the project" and "after the project" situations, but the "without the project" and "with the project" ones;

- considering the impact of working capital requirement, necessary for the functioning of the production assets created during project implementation, on the efficiency of investment projects;

- inflation (accounting for changes in prices for various types of products and resources during project 
implementation) and the possibility of using several currencies in project implementation [13];

- the impact of uncertainties and risks in project implementation.

One of the principal issues is the process of cash flow discounting in evaluation of investment projects efficiency in petrochemical companies. The cash flow of investment projects (CF) is a combination of incoming receivables and payments throughout project implementation. At each step of the projection period, the value of the cash flow is characterized by: 1) inflow equal to the amount of incoming receivables (or results in monetary terms) at this step; 2) outflow equal to payments at this step.

Inflows and outflows account balance provides the value of cash flow. The sequence of cash flow values for consecutive time intervals reflects the cash flow of the project.

The simplest formula for calculating the value of cash flow is: Net profit + Depreciation - Capital investments - Working capital expenditures.

The fundamental concept underlying the assessment of investment projects economic efficiency is time value of money (cash flow). A mechanism, allowing to bring the cash flow values of different time (related to different intervals of calculations) to their value at a certain point in time (point of reduction), is called discounting. The date of estimating the project economic efficiency or the date of project costs commencement are commonly used as a point of reduction.

The discounting (reduction) operation is carried out by multiplying the cash flow value of each year by the corresponding factor (index) of discounting. It should be taken into consideration that, as a rule, a production unit receives revenues and undertakes expenditures evenly over the course of the year, therefore, cash flow discounting should start from the middle of the period. It is recommended to use the following key performance indicators of the projects in petrochemical companies: NPV (Net Present Value); IRR (Internal Rate of Return); project payback period (non-discounted / discounted).

\section{Creating the methodology for estimating the performance indicators of investment projects in petrochemical companies}

Among the standard prerequisites for calculating the performance indicators of investment projects in petrochemical companies, we assume the following:

- prices of raw materials / products (responsible Department of Statistics of the company);

- semi-variable costs (responsible - Department of Economics of the company);

- cost increase deflators - the indices used to recalculate costs in current year prices to the prices of projected years (responsible - Predictive-Analytical Department of the company);

- currency rates (responsible - Predictive-Analytical Department of the company);
- inflation rates (responsible - Predictive-Analytical Department of the company);

- transportation rates (responsible - Department of Statistics);

- volumes of raw materials/products markets (responsible - Department of Economics of the company);

- raw materials/products supply and demand balance (responsible - Department of Economics of the company);

- customs duties (responsible - Department of Economics of enterprises of the company);

- current investment portfolios of the company's projects (responsible - Investment Department of the company).

In case if the required data is absent in the above described investment model, for calculations it is possible to resort to the data of the project initiator, agreed upon with the relevant specialized divisions of the petrochemical company [14].

The other prerequisites for calculating the performance indicators of investment projects of petrochemical companies include:

- discounting rate - corresponds to the nominal (inflation-adjusted) weighted average cost of capital (WACC) of the company. The Corporate Controlling Department is responsible for calculating WACC.

- settlement currency - Russian rouble.

- the projected period is 15 years from the start of capital investments, in case if the lifetime of the main equipment is less than 15 years, the planning horizon equals the lifetime of the main equipment.

- step value (calculation interval) - 1 year.

- fixed assets maintenance costs - are to be accounted for in the amount necessary to maintain fixed assets in working condition.

- income tax rate - according to the changes in the Tax Code of the Russian Federation.

- property tax rate - according to the changes in the Tax Code of the Russian Federation.

It is relevant to consider the procedure of capital investments indexation for cost scheduling purposes. The general indexation mechanism is as follows: in order to determine the amount of capital expenditures by year on the planning horizon, the following growth indices (deflators) should be applied to the assessment of capital investments in current prices: 1) the USA producer price index for costs in US dollars or euros; 2) the Russian Federation producer price index for costs in Russian roubles.

When evaluating the amount of capital investments, the projected rouble-dollar or euro (or others) rate should be taken into account depending on the currency of equipment or services [13].

Evaluating capital costs for the construction project with scheduling is carried out in the following way:

Stage 1. The initial information for evaluating the amount of capital expenditures for the construction project is a summary cost estimate calculated in base prices of base year. 
Stage 2. Next, the costs of works that will be performed by the production unit itself and do not require funding are determined, in prices of base year.

Stage 3 . The costs evaluated at Stage 2 are subtracted from the total estimated construction costs.

Stage 4. The remaining balance establishes the baseline for capital expenditures for the construction project (in current prices for the time of making decision on project implementation). For this purpose, the indices of changes in the current estimated cost to base prices, approved by regional pricing centres are applied. In case of the absence of approved indices for the quarter, when the decision on project implementation is made, it is allowed to use the approved indices for the previous quarter.

As a result of the implemented steps within the methodology for creating a scheduled plan for project financing, a preliminary project schedule in current prices will be drawn up. The preliminary scheduled plan for project financing is a working document to be followed by the approved schedule of financing the project of investment activity. When working out the preliminary scheduled plan for project financing, the costs from the summary cost estimate of construction, in current prices, are distributed by types and quarters of the current year, with the exception of works performed by the production unit itself.

With a project implementation period of more than one year, the costs of subsequent periods are reflected in the financing schedule as a total sum by year of implementation, without a breakdown into quarters. Next, the following approved schedule of financing the project is created (taking into account the increased/ changed cost items), which reflects the changes in construction costs throughout the entire period of project implementation [15].

To calculate the index of increased costs based on industry price indices (deflators), quarterly indices (deflators) are identified. When calculating the increased cost of capital investments, it is assumed that the rise in prices takes place gradually throughout the year. Thus, the calculated quarterly coefficients are identified by extracting the fourth root of the value of the annual index (deflator). For companies that do monthly planning, it is possible to use estimated monthly coefficients, which are determined similarly, by extracting the twelfth root of the value of the industry price index.

When arranging a scheduled plan for project financing for approving, the total capital expenditures in the corresponding quarters are multiplied by the corresponding values of quarterly indices (deflators).

The first quarter is the one, in which the decision on project implementation was made. At its beginning, the estimated cost is to be transformed in current prices, in the manner specified for the estimates, and then in scheduled planning, as the project progresses, the appreciation of the remaining estimated costs is based on quarterly indices (deflators).

As construction projects can be put into operation not only at the beginning or the end of the period, but also throughout the quarter, the calculations may require the index value (deflator) for the mid-quarter, which in this case is calculated as the arithmetic average between the quarterly index value (deflator) at the beginning of the quarter and at its end. Meanwhile, for the first quarter, after making the decision on project implementation, the index (deflator) is only half the value of the corresponding index (deflator) for the period.

\section{Calculation of the index of increased costs of investment projects in petrochemical companies according to the proposed methodology}

Example 1. Let us calculate a construction project, being implemented during the year:

- index (deflator) of prices for Russian industry for base year: $8.25 \%$;

- capital expenditures for the project construction (except for the cost of in-house, non-contracted construction) in current prices for the $1^{\text {st }}$ quarter of base year: 20000 thousand roubles, VAT included;

- resolution date on implementing the project: January of base period;

- project start: mid-2 ${ }^{\text {nd }}$ quarter of base year;

- project finish: mid- $4^{\text {th }}$ quarter of base year.

Calculation model of the increased cost of equipment for Example 1 is represented in Table 1.

Example 2. Let us calculate a construction project, being constructed during the year and rolling over to the following year:

- index (deflator) of prices for Russian industry for base year: $8.25 \%$;

- the index (deflator) of prices of the industry of the Russian Federation in the year following base year: $7.65 \%$;

- the estimated cost in current prices of the $4^{\text {th }}$ quarter of base year: 30000 thousand roubles, VAT included;

- project start: the beginning of the $4^{\text {th }}$ quarter of base year;

- project finish: mid- $3^{\text {rd }}$ quarter of the year following base year.

Calculation model of the increased cost of equipment for Example 2 is represented in Table 2.

Additionally, it should be mentioned that if a project presupposes the purchase of imported equipment, then for correct cost planning, it is necessary to set aside some amount of capital expenditures for the purchase of imported equipment. To calculate the increase in the cost of equipment, it is necessary to use the price index of the US industry, and the price index of Russian industry to calculate the remaining part of the capital expenditures on the construction project. In both cases, the calculation method will be identical; the only difference will be in price indices. After recalculating, the amounts with the cost increase are added up to get the total values of the target project costs for the relevant periods. A similar approach will be applied in case of foreign contractors' involvement in the project. The volume of capital expenditures while evaluating their cost at other stages of project consideration (project initiation, project study and justification of investment) is evaluated based on the price indices of the industry, similarly to the method 
Table 1. Calculation of the increased cost of equipment for Example 1.

\begin{tabular}{|c|c|c|c|c|c|}
\hline \multirow[b]{2}{*}{ Indicator } & \multicolumn{5}{|c|}{ Capital investment plan for the project } \\
\hline & $\begin{array}{r}\text { Total for } \\
\text { the project }\end{array}$ & $\begin{array}{l}\mathbf{1}^{\text {st }} \text { quarter of } \\
\text { base year }\end{array}$ & $\begin{array}{r}2^{\text {nd }} \text { quarter } \\
\text { of base year. }\end{array}$ & $\begin{array}{r}3^{\text {rd }} \text { quarter } \\
\text { of base year }\end{array}$ & $\begin{array}{r}4^{\text {th }} \text { quarter } \\
\text { of base year }\end{array}$ \\
\hline $\begin{array}{l}\text { Capital investments in } \\
\text { current prices of the } 1^{\text {st }} \\
\text { quarter of base year }\end{array}$ & 20000 & 0 & 3000 & 4000 & 13000 \\
\hline $\begin{array}{l}\text { Estimated } \\
\text { indices (\% to the } \\
\text { previous period) }\end{array}$ & & $2 \%$ & $2 \%$ & $2 \%$ & $2 \%$ \\
\hline $\begin{array}{c}\text { Quarterly } \\
\text { (deflators) }\end{array}$ & & $\begin{array}{c}(1,00+1,02) / 2 \\
=1,01\end{array}$ & $\begin{array}{l}1,01 * 1,02 \\
=1,0302\end{array}$ & $\begin{array}{l}1,0302 * 1,02 \\
=1,0508\end{array}$ & $\begin{array}{c}1,0508 * 1,02 \\
=1,07182\end{array}$ \\
\hline $\begin{array}{l}\text { Capital investments } \\
\text { with increased cost }\end{array}$ & 21227,5 & 0 & 3090,6 & 4203,2 & 13933,7 \\
\hline
\end{tabular}

Table 2. Calculation of the increased cost of equipment for Example 2.

\begin{tabular}{|c|c|c|c|c|c|}
\hline \multirow{2}{*}{ Indicator } & \multicolumn{5}{|c|}{ Capital investment plan for the project, for the period following base year } \\
\cline { 2 - 6 } & $\begin{array}{c}\text { Total for } \\
\text { the project }\end{array}$ & $\begin{array}{c}\mathbf{4}^{\text {th }} \text { quarter } \\
\text { of base year }\end{array}$ & $\begin{array}{c}\mathbf{1}^{\text {st }} \text { quarter of } \\
\text { the year } \\
\text { following base } \\
\text { year }\end{array}$ & $\begin{array}{c}\mathbf{2}^{\text {nd }} \text { quarter of } \\
\text { the year } \\
\text { following base } \\
\text { year }\end{array}$ & $\begin{array}{c}\mathbf{3}^{\text {rd }} \text { quarter of } \\
\text { the year } \\
\text { following base } \\
\text { year }\end{array}$ \\
\hline $\begin{array}{c}\text { Capital investments } \\
\text { in current prices of } \\
\text { the } 4^{\text {st }} \text { quarter of base } \\
\text { year }\end{array}$ & 30000 & 3000 & 4000 & 13000 & 10000 \\
\hline $\begin{array}{c}\text { Estimated quarterly } \\
\text { indices (\% to the } \\
\text { previous period) }\end{array}$ & $2 \%$ & $1.86 \%$ & $1.86 \%$ & $1.86 \%$ \\
\hline $\begin{array}{c}\text { Quarterly indices } \\
\text { (deflators) }\end{array}$ & $\begin{array}{c}(1,00+1,02) \\
/ 2\end{array}$ & $\begin{array}{c}1,01 *(1,02+1, \\
0186) / 2 \\
=1,0294\end{array}$ & $\begin{array}{c}1,0294 * 1,0186 \\
=1,0481\end{array}$ & $1,0481 * 1,0186$ \\
& $=1,0100$ & 4,0676 \\
\hline $\begin{array}{c}\text { Capital investments } \\
\text { with increased cost }\end{array}$ & 31446,3 & 3030 & 4116 & 13624,3 & 10676 \\
\hline
\end{tabular}

described above. Meanwhile, the volume of investments in current prices is determined by analogues or through consolidated cost indices.

\section{Conclusion and recommendations}

The described methodology is applied to scheduling project costs and is in fact the ground for establishing annual financing limits for a project. In contract pricing, the recalculation of the cost of works and services is carried out according to the rules and standards approved for the estimates in any petrochemical company, inclusive of the indices of changes in current estimated cost to base period prices.

Thus, consistent with all the above, it can be said that the proposed methodology for assessing the performance indicators of investment projects is one of the most multi-faceted and optimal tools for petrochemical companies for attracting additional funding from both their own and other sources. In the conditions of growing business volumes, and in case of complying with the recommendations of the state strategy for the industry growth until 2030, the proposed methodology is transparent and relevant to all the investment participants in terms of cash flow generation for the project.

\section{References}

1. D. Akishin, E. Tyrtov, Difficult petrochemistry. The industry needs support tools, which are available?, Oil \& Gas Journal Russia Available (2018) at: http://vygon.consulting/upload/iblock/1bd/difficult_ petrochemistry_OGJR_12_2018.pdf

2. The strategy for the development of the chemical and petrochemical complex until 2030, Available at:

http://strategy2030.midural.ru/sites/default/files/file s/strategiya_him_i_neftehim_do_2030.pdf

3. The structure of fixed investments in $2002-2017$ by types of fixed assets, Official website of the Federal State Statistics Service. Available at: http://www.gks.ru/wps/wcm/connect/rosstat_main/r osstat/ru/statistics/enterprise/investment/nonfinanci $\mathrm{al} / \#$

4. World Bank WB 2017 World Development Indicators,
Database, 
http://data.worldbank.org/data-catalog/worlddevelopment-indicators.

5. Petrochemistry as a driver for the hydrocarbons demand 2018 http://ac.gov.ru/files/publication/a/19162.pdf

6. D.M. Pociovălişteanu, E. Thalassinos, A. Ţîrcă, Filho W L Trends and challenges in the energy sector of Romania in the post-accession to the European Union, International Journal of Environmental Technology and Management, 12(1), 3-15 (2010)

7. L. Coenen, J.F. Díaz López, Comparing systems approaches to innovation and technological change for sustainable and competitive economies: An explorative study into conceptual commonalities, differences and complementarities, Journal of Cleaner Production, 18(12), 1149-1160 (2010)

8. H. Mandery, Petrochemical feedstocks: the cornerstone of competitiveness, Concawe review, 23(1), 45-46 (2014)

9. B. Sucic, F. Al-Mansour, M. Pusnik, T. Vuk, Context sensitive production planning and energy management approach in energy intensive industries, Energy, 108, 63-73 (2016)

10. P. Antunes, P. Carreira, M. Mira da Silva, Towards an energy management maturity model, Energy Policy, 73, 803-814 (2014)

11. P. Diwan, A. Kazmi, M. Washid, Strategic Investment Decisions in Petrochemical Sector: A Comparative Study of GCC Coutries, Pentagon Energy Press, New Delhi, India (2009) https:/www.isc.hbs.edu/resources/courses/moccourse-at-harvard/Documents/pdf/studentprojects/UAE $\% 20$ Petrochemical $\% 20$ Cluster\%20Re port $\% 20$ Final $\% 20$ May\%2004\%202012.pdf

12. S. Yau, R.H. Kwon, J. Scott Rogers, D. Wu, Financial and operational decisions in the electricity sector: Contract portfolio optimization with the conditional value-at-risk criterion, International Journal of Production Economics, 134 (1), 67-77 (2011)

13. E.J. Thalassinos, E.D. Politis, The evaluation of the USD currency and the oil prices: A var analysis, European Research Studies Journal, 15(2), 137-146 (2012)

14. A. Shuen, P.F. Feiler, D.J. Teece, Dynamic capabilities in the upstream oil and gas sector: Managing next generation competition, Energy Strategy Reviews, 3(C), 5-13 (2014)

15. M. Gangolells, M. Casals, N. Forcada, M. MacArulla, A. Giretti, Energy performance assessment of an intelligent energy management system, Renewable and Sustainable Energy Reviews, 55, 662-667 (2016) 